\title{
Education of English for Specific Purposes in Tunisia: The case of the faculty of medicine of Sousse
}

\author{
Abdelfatteh Harrabi \\ The Higher Institute of Applied Studies to Humanities of Mahdia, Tunisia.
}

\begin{abstract}
This study aims to describe the educational situation of English for Specific Purposes within the faculty of medicine of Sousse, Tunisia. In order to explore the attitudes of both teachers and learners in this institution, a questionnaire and an interview were adopted. Scrutiny of the results shows that a big majority of students are aware of the importance of English in their study as well as their future professional life. Nevertheless a change needs to take place concerning the time table, the content of the course.., etc. Ultimately, this study aims to improve the teaching/learning situation of English for Specific Purposes in Tunisian higher education.
\end{abstract}

Keywords: ESP, learning, teaching, attitudes, learning a second language.

\section{INTRODUCTION}

Over the past few decades, researchers and practitioners have been emphasizing how the teaching and learning of English in universities where English is a foreign language can best help students to perform more successfully in their disciplines and professional contexts (Adams \& Keene 2000[1]; Herrington \& Moran1992[2]; Hutchinson \& Waters, 1987[3]; Johns, 2003a[4], 2003b[5]; Leki, 2003[6], Seshadri \& Theye, 2001[7]; Swales \& Mustafa, 1984[8]). A wealth of studies indicate that English as a Foreign Language programs can no longer be seen as being separable from other disciplines, but have an important role in helping to initiate students into the academic community in acquiring not only the language proficiency necessary but the specific genres pertaining to these communities (Bacha, 2003 [9]; Bhatia \& Candlin, 2000[10]; Canagarajah, 2002[11]; Mukattash, 2003[12]; Nickerson, Gerritsen, \& Meurs, 2005[13]; Zhu, 2004[14]). Jackson[15] summarizes the status of EFL programs in that "simpler more traditional language support courses may no longer be adequate in today's complex world." (2005: 305)

Investigation has also focused on disciplinary and interdisciplinary teaching of English. Research results have indicated student gains in programs designed according to English for Specific Purposes (ESP) in which collaboration and team teaching between the English teaching and concerned discipline faculty have taken on significant dimensions in the students' language acquisition and literacy for a purpose (Creese, 2000[16]; Flowerdew, 1990[17]; Flowerdew \& Peacock, 2001[18]; Gardner, 2003[19]; Haynes, 2002[20]; Johns \& Swales, 2002[21]; Jones, Turner, \& Street, 1999[22]; Jordan, 1997[23]; Leki, 2003; Richards, 1996[24]; Street \& Verhoeven, 2001[25]; Warschauer, 2002[26]).

The teaching of English for Specific Purposes is well developed in the European countries. However, in Tunisia, one notes that there has been a recent increase in the number of institutions of higher education coupled with a diversity of literary and scientific specialities as well as an increase in the number of students attending these institutions (Chabchoub, 2002[27]). This increase in the number of the university structures, especially of scientific and technological specialities, was not accompanied by any development in teaching programs, and in particular as pertains to the teaching of English for Specific Purposes. The current situation regarding the teaching of this specialty in the non-literary institutions is characterized especially by a lack of human resources and adequate teaching material.

Knowing the attitudes of learners and teachers of English for Specific Purposes is of paramount importance before undertaking any action aiming at improving the teaching/learning of this specialty. For, the attitude of the learner plays a considerable role in second language learning (Bogaards, 1990[28]).

In the same way, teachers play an essential part in this operation of teaching/learning English for Specific Purposes. It is the teacher who puts into practice the learning tasks and minimizes the constraints, who organizes the activities and fits them in the context of learning (Pendanx, 1998[29]).

In Tunisia we don't have enough information concerning the English for Specific Purposes teaching/learning situation. The aim of this study is to describe the situation of the teaching of English for Specific Purposes in Tunisia through the attitudes of the teachers and the students belonging to the faculty of medicine of Sousse. The study, thus, is an inquiry into purposeful English teaching in the medical discipline, which could be a significant contribution since no study of the kind was done in this research field. 


\section{INSTITUTIONAL CONTEXT}

\section{a. Background to the Medical English course}

Arabic is the national language in Tunisia and English is taught as a foreign language. All subjects are taught in Arabic and French at the majority of universities, while English is included in the curriculum as a compulsory subject. The purpose is to raise the students' proficiency in medical settings as well as to prepare them for successful communication in their future profession.

The course takes place over two academic semesters, a duration of 30 weeks and the total length is 90 hours (1,5 hours/day; 2 days/week). Group sizes are usually between twenty five and thirty five students.

In the absence of a specific training before the teaching of English for medical purposes, the medical English teachers made the medical English course run parallel to those subject courses in which students can relate their subject knowledge to the medical English context. The target learners' performance is assessed at the end of the semester because the course is compulsory along with other subjects. It focuses broadly on the three basic language skills of reading, writing and speaking.

\section{b. Outline for the whole course}

The course covers three language areas - writing, speaking and reading in which the following are taught:

Speaking: Introductions; job interview; using the telephone; conversations.

Writing: Resume; job application letters; medical letters; e-mails; notes; memos.

Reading: Medical documents; newspaper articles.

\section{c. Goals and objectives}

The overall aim of the course is to fully prepare students for their future career because after the graduation they are likely to seek employment in international companies. Before recruitment, resumes are sent out to companies and interviews are conducted, therefore, job application constitutes a vital part of the course. In their future medical career, they may find themselves working in a company where English is widely spoken, or using English as a medium of communication with other people in the medical field from all over the world.

By the end of the course, learners should be able to familiarize themselves with medical terminology and write competently in English. For example, they should be capable of writing appropriate medical letters, emails as well as a good resume. They must have the ability of understanding intermediate medical articles and newspapers, understanding and conducting general conversation in medical contexts as well as maintaining relationships with the target community.

The objectives for each skill are as follows:

Speaking: To communicate effectively with native speakers in job interviews as well as medical settings.

To respond effectively to telephone messages and job interviews

Reading: To understand a variety of texts, such as medical reports, documents and newspaper articles.

Writing: To write resumes and medical-related letters or e-mails.

\section{a. Study design}

\section{MeTHODOLOGY}

We have used a cross sectional study to describe the situation of teaching/learning of English for Specific Purposes in the Tunisian higher education.

\section{b. Population}

The studied population was composed of both the English teachers and the students of the faculty of medicine of Sousse. All the English teachers of this institution were included in the study and a class of students was picked out randomly (all the classes of the institution were numbered, a simple random picking out was done and a class was selected and included in the study).

\section{c. Data collection}

The data were collected using a self administered and anonymous questionnaire for students and an interview for teachers.

\section{i. Questionnaire}

The questionnaire adopted in the present study depends on the particular nature of the set of themes. I was initially based on the personal criteria of age, sex as well as the socio-demographic characteristics to draw a distinction between learners. The specialty before undertaking the higher education is also used as a parameter in the questionnaire in order to determine the importance of English language. We have also collected 
information about the number of hours of English language learning, the time table and their influence on the learning of English, and the students' point of view towards the teaching aids.

\section{ii. Interview}

The four English teachers pertaining to the faculty of medicine of Sousse were contacted and a discussion with each teacher during approximately thirty minutes was carried out. The interview included general questions related to the identification of teachers (level of study, the date of obtaining the last diploma), the regular training and the training for the teaching of English for Specific Purposes, the teaching material most used for the teaching of this subject, the number of students per group and its impact on teaching/learning English, as well as the opinions of the teachers concerning the importance of a national coordinator among the teachers of English for Specific Purposes in Tunisia.

\section{RESULTS}

\section{a. Learners}

\section{i. General Characteristics}

The studied population included 30 third year students at the faculty of medicine of Sousse. These students were aged between 20 and 25 years. The average age of this population was 21 years. The percentage of males slightly exceeded that of females in the studied population. In fact, $40 \%$ of this population were males whereas $60 \%$ were females. These students obtained their bachelor's degree in different sections. The students who had the bachelor's degree in the specialty of mathematics represented $53 \%$ of the population, while the students who had a bachelor's degree in the specialty of science represented $32 \%$ of it. The students who had a bachelor's degree in the specialty of economics and management represented only $15 \%$ of the whole population.

\section{ii. Institutional context}

The students of medicine had a three hour English course a week. The majority of these English studies were done during the afternoons. These students had English averages going from 6 to 18 out of 20 .

\section{iii. Importance of English for Specific Purposes}

The answers showed that $100 \%$ of the students of medicine considered English for Specific Purposes as important. The number of hours of the English course was very sufficient for $20 \%$ of the students, while students who considered this number as sufficient were $50 \%$ of the population $30 \%$ of them affirmed that the number of hours of the learning of English was not sufficient.

The majority of the students of medicine were satisfied with the English for Specific Purposes time table. In fact, $80 \%$ among them mentioned that the schedules of learning English were suitable.

Moreover, the majority of learners preferred smaller class sizes during the learning of English for Specific Purposes. In fact, $75 \%$ among them wanted to learn English for Specific Purposes in groups with a number between 15 and 20 students.

The contents of the courses were seen by $95 \%$ of the students as adapted and adaptable to their future professional life whereas $5 \%$ said that these contents of course were neither adapted nor adaptable to their future professional life.

The rate of motivation $(100 \%)$ of the students of medicine for the learning of English for Specific Purposes showed that all students were motivated to study this subject.

The distribution of learners according to the geographic placement showed that $90 \%$ of the students belonged to urban environment and $10 \%$ of the students were from the rural area. The motivation according to the place of origin showed that $85 \%$ of the students in the urban environment were more motivated for the learning of English for Specific Purposes whereas only 15\% of the students belonging to the rural area were motivated for the learning of English for Specific Purposes.

It is also important to note that the percentage of the girls who were motivated for the learning of English for Specific Purposes was $60 \%$, whereas the percentage of the boys who were motivated for the learning of this subject was $40 \%$.

A great majority of students considered that the English teaching at university was not more motivating than that of the secondary education. In fact, $70 \%$ of the students of medicine said that the teaching of English at university was not motivating.

Concerning teaching aids, $80 \%$ of the students of medicine were in favor of the use of worksheets during the courses of English. The figures show that $40 \%$ of the students agreed completely with the use of the audio-visual aids during the English courses and $40 \%$ of them partially agreed with the usage of this teaching aid whereas only $20 \%$ of them totally disagreed with the usage of audio visual aids. Indeed $70 \%$ of the students agreed completely with the use of the multimedia means during the English courses. Group work during the English courses was approved by $70 \%$ of the students. 


\section{b. Teachers}

i. Identification

All the interviewed teachers belong to the faculty of medicine of Sousse. The last diploma of all these teachers is the Bachelor of Arts in English language and literature.

\section{ii. Suggestions of the ESP teachers}

All the English teachers insisted on the fact that they did not receive any pre-service training for the teaching of English for Specific Purposes. They expressed the need for a continuous training in anglophone countries. These teachers insisted on the importance of an initial training that would initiate the English novice teachers to practical questions concerning teaching/learning of English for Specific Purposes. For example, they indicated that an initial training during the last year of the English studies for the students who were specialists of English and a similar training after the Bachelor of Arts would be a beneficial preparation for each student before "being plunged" directly in the English for Specific Purposes teaching. This initial training could be supplemented by a continuous training while the teacher was already in profession. In this context, these teachers proposed an exchange between students and teachers of English for Specific Purposes so that students could have a direct contact with the professional context.

The interlocutors insisted on the importance of collective work between the teachers of English for Specific Purposes. In this respect, they evoked the need for mutual aid and cooperation between the teachers of English Specific Purposes in the same institution and various institutions of higher education in Tunisia concerning the preparation of the courses, examinations and even for the programs.

\section{DISCUSSION}

The analysis of the situation of teaching/learning of English for Specific Purposes in Tunisia is of paramount importance and this is for different reasons. On the one hand, there was no work devoted to the study of this situation in our country. In addition, the number of students and the non literary institutions has been in increase for a number of years and this increase requires an exploration of the situation of teaching/learning of this specialty.

\section{a. Main results}

Through the questionnaires, one noted that the majority of learners were motivated for the learning of English for Specific Purposes. In addition, these learners regarded the teaching of English for Specific Purposes in the higher education as not motivating. A great percentage of learners preferred the use of the multimedia means, as well as the audio-visual aids in the English courses. The majority of the students wanted to work in groups during the English meetings.

The interviews with the teachers of English for Specific Purposes in the faculty of medicine of Sousse showed the lack of specific training and continuous training for the teaching of English for Specific Purposes. All the teachers preferred the creation of a continuous training as well as the existence of the multimedia means, the audio-visual supports, and teaching equipment specific to the teaching of English for Specific Purposes in their institution. These teachers suggested national coordinators who could connect the English for Specific Purposes teachers of the whole country.

\section{b. Interpretation of the results \\ i. Motivation}

The results of this study showed the various attitudes of the students and teachers towards the teaching/learning of English for Specific Purposes in the faculty of medicine of Sousse. All the students expressed their motivation for the learning of this subject. This motivation is due to several factors. Zimmermann (1990) defines motivation as a dynamic process which has its origins in perceptions that a learning subject has of himself and of his environment and which incites him to choose an activity, to undertake it in order to achieve his goals. This proves that motivation is not a fixed state, but rather a dynamic process generated by exterior factors (like the perception of the environment in which the subject evolves) and of interior factors (like self-esteem).

Within this framework, the teacher can be a motivating factor for the learning of the academic activities in general and the foreign languages in particular. He can convince his students of the interest of the foreign languages and create a mobilizing context for them. Consequently, the student will perceive positively the language to be studied and if he feels able to accomplish success in it, to be able to control it. His cognitive engagement in mastering the language and his perseverance will enable him thereafter to carry out good performance.

The socio-cognitive studies carried out on motivation (Bandura, 1986[30]) show that motivation is determined by various perceptions from the learner: perception of himself, of the value of the activity to be 
undertaken, of his competence to accomplish the learning task, and the perception of the controllability of the task.

The perception of oneself is related to the whole of the beliefs and of the general representations that a person develops of himself. Students' self representations are generally subjective. Thus, a given student may judge himself as unable to learn a particular language while he can actually do. This short analysis shows already the importance of the perception of oneself in the process of motivation. This importance for example led Bandura (1986) to reaffirm that with equal competences, these perceptions are more important than the students' intellectual abilities for their ultimate success.

Through our analysis, we noted that the majority of the students were conscious of the importance of this language in their future professional life as well as for the success in their higher education. In this regard, Mary Schleppegrell says that older adults learn a foreign language for a specific purpose "to be more effective professionally, to be able to service in an anticipated foreign situation or for other instrumental reasons" (Schleppegrell, 2008, p. 3[31]). So a task to be undertaken in English for Specific Purposes is judged according to whether it allows or not the student to achieve his goals. As Donna (2000, p. 3[32]) explains:

Even students who are tired and preoccupied and apparently uninterested in English can

become highly motivated if the need for English in their works is made clear to them.

Consequently, the positive perception of the value of academic work has an influence on the motivation of students for the learning of English for Specific Purposes. Indeed, if the student does not perceive the utility of this subject, it is extremely probable that he will not be motivated to study it.

\section{ii. Group work}

More than half of the students saw the teaching of English at university as not motivating and almost the same percentage favors group work during the English course. In pedagogical terms, what I propose is that teachers should take into consideration the merits of effective group work in the classroom. Teachers should foster group cohesion and instruct students on the true meaning of unequal contribution in the group. According to Michaelsen, Fink and Knight (1997[33]) a way to promote the development of cohesive groups is to motivate discussion among members of the group. They suggest that if teachers require from students to make a concrete decision in order to apply a rule or solve a problem, then everyone in the group have the opportunity and the incentive to participate in completing the task because genuine member input is a valuable resource. This finding accords with the suggestions made by Mingzhi (2005[34]). He proposes that the student workshop or presentation is very helpful in enhancing interaction in an EFL classroom because students will be required to demonstrate the techniques they have learned and play the role of the teacher in class. This suggestion explains why unequal contribution helps in the formation of a harmonious sociological climate within the group members.

When students work in groups individual high achievement of a group member is favored by his/her co-workers because maximum group achievement is attained. Thus since high achievers help the weaker ones, their bonds become stronger and the result is positive. Group productivity reaches a peak and co-workers feel accepted. Also this way enables students to work autonomously away from their tutor. Thus, students realize the importance of the task in relation to student goals within the group. This finding is in accordance with the conclusions of a survey carried out by Peterson and Miller (2004, p.180[35]) and some observations made by Katsara, O. (2006, pp. 16-17[36]) within the context of an ESP classroom.

\section{iii. Audiovisuals and multimedia}

A great majority of learners expressed their predilection for the use of the multimedia means as well as the audiovisual material in the preparation of the courses by their English teachers. In fact, the use of the audiovisual material such as the overhead projector, cassettes, and videos during the English courses has many teaching advantages which enhance the communication with the students.

In addition, the use of multimedia during the English courses constitutes the basis for autonomous work because learners can profit from a personalized sequence guided by a well defined program via hypertext techniques. Barnes (1994[37]) states that hypertext is unique. This is because it enables readers to pick and choose blocks of text by interacting with the machine. It is a way of organizing information and browsing through electronic texts stored on individual computers and networks. Hypertext includes "a wide range of computer applications such as interactive books, encyclopedias, online reference indexes, and other forms of nonlinear reading and writing which are created by means of computer technology" (p. 26). This practice can largely help the personal work of the students; it also allows more argued answers concerning a medical subject. Indeed, communication and information technologies make it possible to consult not only a multitude of sites and documents but also online anglophone experts to obtain more argued answers concerning a medical subject. The last possibility allows not only communications and interactions by videoconferences or e-mails, but also to open the teaching/learning of English for Specific Purposes to the world. 


\section{CONCLUSION}

The present paper was related to the exploration of the situation of teaching/learning of English for Specific Purposes in the Tunisian higher education through the faculty of medicine of Sousse. Thus, through the questionnaire and the interview, we highlighted the remarks related to the subject. After the diagnosis of the situation of teaching/learning of English for Specific Purposes, it was proved that the teaching material such as audiovisuals, new technologies and multimedia were lacking. However, through the bibliographical study, several researchers in English for Specific Purposes field stress the importance of the use of this material for the progress of the English for Specific Purposes' teaching/learning operation.

It would be thus interesting to think of improving the situation in this field in Tunisia. This improvement could be carried out by introducing the use of the audiovisual and multimedia means as well as by offering trainings to the teachers of English for Specific Purposes.

\section{REFERENCES}

[1] Adams, K., \& Keene, M. (2000). Research and writing across the disciplines (2nd ed.). California: Mayfield Publishing Company.

[2] Herrington, A., \& Moran, C. (Eds.). (1992). Writing, teaching, and learning in the disciplines. New York: The Modern Language Association of America.

[3] Hutchinson, T., \& Waters, A. (1987). English for Specific Purposes: A learning centered approach. Cambridge: Cambridge University Press.

[4] Johns, A. (2003a). Genre in the classroom: Multiple perspectives. Mahwah, New Jersey: Lawrence Erlbaum.

[5] Johns, A. (2003b). Genre and ESL/EFL composition instruction. In B. Kroll (Ed.), Exploring the dynamics of second language writing (pp. 195-217). Cambridge: Cambridge University Press.

[6] Leki, I. (2003). Living through college literacy: Nursing in a second language. Written Communication: An International Quarterly of Research, Theory, and Application, 20(1), 81-98.

[7] Seshadri, S., \& Theye, L. (2001). Professionals and professors: Substance or style? Business Communication Quarterly, 63(3), 923.

[8] Swales, J. M., \& Mustafa, H. (Eds.). (1984). English for Specific Purposes in the Arab world. Birmingham, UK: Language Studies Unit, University of Aston.

[9] Bacha, N. N. (2003). English across academic and professional communities: A study of EFL learners' needs at the Lebanese American University. The Official Journal of the Association of American International Colleges and Universities, $2,33-62$.

[10] Bhatia, V., \& Candlin, C. (2000). Multifaceted needs analysis in business education: Dimensions of professional discourse: new challenges for ESP. In Paper presented at the Annual TESOL Convention, Vancouver, March 2000.

[11] Canagarajah, S. (2002). The geopolitics of academic writing. Pittsburg: University of Pittsburg Press.

[12] Mukattash, L. (2003). Towards a new methodology for teaching English to Arab learners (TEAL). International Journal of ArabicEnglish Studies, 4, 211-234.

[13] Nickerson, C., Gerritsen, M., \& Meurs, F. V. (2005). Raising student awareness of the use of English for specific business purposes in the European context: A staff-student project. English for Specific Purposes, 24(3), 334-345.

[14] Zhu, W. (2004). Faculty views on the importance of writing, the nature of academic writing, and teaching and responding to writing in the disciplines. Journal of Second Language Writing, 13, 29-48.

[15] Jackson, J. (2005). An inter-university, cross-disciplinary analysis of business education: Perceptions of business faculty in Hong Kong. English for Specific Purposes, 24(3), 293-306.

[16] Creese, A. (2000). The role of the language specialist in disciplinary teaching: In search of a subject. Journal of Multilingual and Multicultural Development, 21(6), 461-470.

[17] Flowerdew, J. (1990). English for Specific Purposes - A selective review of the literature. English Language Teaching Journal, 44(4), 326-337.

[18] Flowerdew, J., \& Peacock, M. (2001). Issues in EAP: A preliminary perspective. In J. Flowerdew \& M. Peacock (Eds.), Research perspectives on English for academic purposes (pp. 8-24). Cambridge: Cambridge University Press.

[19] Gardner, L. (2003). Writing across the disciplines for learning excellence. School of Business/Department of Mathematics, Indianapolis, unpublished paper.

[20] Haynes, C. (2002). Innovations in interdisciplinary teaching. Westport, Connecticut: American Council on Education, Oryx Press.

[21] Johns, A. M., \& Swales, J. M. (2002). Literacy and disciplinary practices: Opening and closing perspectives. Journal of English for Academic Purposes, 1(1), 13-28.

[22] Jones, C., Turner, J., \& Street, B. (1999). Students writing in the university: Cultural and epistemological issues. Philadelphia: John Benjamins Publishing Company.

[23] Jordan, R. R. (1997). English for academic purposes: A guide and resource book for teachers. Cambridge: Cambridge University Press.

[24] Richards, D. (1996). The meaning relevance of synthesis and interdisciplinary studies. The Journal of General Education, 45, 14128 .

[25] Street, B., \& Verhoeven, L. (Eds.). (2001). Studies in written language and literacy. London: Routledge. 92 N.N. Bacha, R. Bahous / English for Specific Purposes 27 (2008) 74-93

[26] Warschauer, M. (2002). Networking into academic discourse. Journal of English for Academic Purposes, 1(1), 45-58.

[27] Chabchoub, A. (2002). Manuel de pédagogie universitaire. Tunis: ATED

[28] Bogaards, P. (1991). Aptitude et affectivité dans l'apprentissage des langues étrangères. Paris: Didier.

[29] Pendanx, M. (1998). Les activités d'apprentissage en classe de langue. Paris : Hachette.

[30] Bandura, A. (1986). L'apprentissage social. Bruxelles : Madraga.

[31] Schleppegrell, M. (2008). The older language learner. The National Teaching and Learning Forum. Retrieved on Sept. 24, 2008 from http://www.ntlf.com/html/lib/bib/87-9dig.htm.

[32] Donna, S. (2000). Teach Business English. Cambridge: Cambridge University Press.

[33] Michaelsen, L.K., Fink, L.D., \& Knight, A. (1997). Designing Effective Group Activities: Lessons for Classroom Teaching and Faculty Development. In DeZure, D. To Improve the Academy: Resources for Faculty, Instructional and Organizational Development, Stillwater, OK: New Forums.

[34] Mingzhi, X. (2005). Enhancing interaction in our EFL classroom, CELEA Journal, Vol28 (2), 56-62. 
[35] Peterson, S. E., Miller, J. A. (2004). Comparing the Quality of Students' Experiences During Cooperative Learning and LargeGroup Instruction, The Journal of Educational Research, Vol 97 (3), 123-133.

[36] Katsara, O. (2006). Enhancing student motivation by promoting and evaluating communication among themselves, TESOL Greece Newsletter, No90 April- June, 16-17.

[37] Barnes, S. (1994). Hypertext literacy. Interpersonal Computing and Technology, 2(4), 24-36. 